\title{
PENERAPAN MODEL KOOPERATIF TIPE STAD UNTUK MENINGKATKAN KEMAMPUAN PEMBELAJARAN PKN SISWA KELAS VI SDN 018 KUOK
}

\author{
Darnayus \\ Guru SDN 018 Kuok \\ Darnayus.darna@gmail.com
}

\begin{abstract}
ABSTRAK: Penelitian ini bertujuan untuk meningkatkan hasil belajar PKN siswa kelas VI SDN 018 Kuok. Penelitian ini merupakan penelitian tindakan kelas yang dilaksanakan dalam dua siklus 6 kali pertemuan. Subjek penelitian ini adalah siswa kelas VI yang berjumlah 17 orang. Data penelitian ini didapat melalui lembar observasi (perilaku aktivitas belajar siswa, perilaku aktivitas kerja kelompok) dan hasil belajar siswa. Hasil penelitian menunjukan bahwa penerapan model pembelajaran kooperatif tipe STAD dengan siklus 1 perilaku aktivitas belajar siswa aspek kedisiplinan 73,45; kesiapan belajar 72,75; keberanian 74,10; tanggung jawab 58,78 dan pemahaman tugas 60,74, pada siklus 2 mengalami peningkatan aspek kedisiplinan 85,75; kesiapan belajar 84,44; keberanian 86,41; tanggung jawab 83,05 dan pemahaman tugas 85,19 sedangkan perilaku aktivitas kerja kelompok aspek kerjasama 69,44; menyelesaikan masalah 66,66; percaya diri 63,89 dan hasil kerja kelompok 86,11, pada siklus 2 mengalami peningkatan kerjasama 86,11; menyelesaikan masalah 86,11; percaya diri 83,33 dan hasil kerja kelompok 97,22 sedangkan hasil belajar siklus 1 ketutasan 52,94 \% mengalami peningkatan 94,12\% dan rata-rata kelas 72,33 meningkat pada siklus 2 menjadi 84,47. Jadi, penerapan model pembelajaran kooperatif tipe STAD dapat meningkatkan perilaku aktivitas belajar siswa dan perilaku aktivitas kerja kelompok setiap pertemuan sehingga hasil belajar siswa pun ikut meningkat.
\end{abstract}

Kata Kunci. Kooperatif, STAD, Hasil Belajar, PKn. 


\title{
THE IMPLIMENTATION OF STAD TYPE COOPERATIVE MODELS TO INCREASE PKN LEARNING ABILITY STUDENT CLASS VI SDN SDN 018 KUOK
}

\begin{abstract}
The aim of this classroom action research was to improve the student's ability in PKN. The sample respondents were 17 students of SDN 018 Kuok. Before the treatment was conducted, the sample was given pre-test and after the treatment, post-test was also held. The results showed that the application of the STAD type cooperative learning model with cycle 1 of the disciplinary aspects of student learning activity 73.45; learning readiness 72,75; courage 74,10; responsibility aspects 85.75 ; learning readiness 84.44 ; courage 86.41 ; responsibility 83.05 and understanding of tasks 85.19 while the behavior of group work activities cooperation aspects 69.44; solve problems 66.66; confidence 63.89 and the work of the group 86.11, the second cycle increased cooperation 86.11; solve problems 86.11; self-confidence 83.33 and group work results 97.22 while the learning outcomes of the first cycle of 52.94\% experienced an increase of $94.12 \%$ and the average class 72.33 increased in cycle 2 to 84.47. So, the application of the STAD type cooperative learning model can improve the behavior of student learning activities and the behavior of group work activities at each meeting so that student learning outcomes also increase.
\end{abstract}

Keywords: Cooperative, STAD, Learning Outcomes, PKn

\section{PENDAHULUAN}

Pendidikan sebagai akar utama dalam menumbuhkan semangat pembangunan sangat diperlukan oleh semua stake holder untuk mengimbangi derasnya arus globalisasi. Peran pendidikan semakin berat, yaitu bagaimana mempersiapkan manusia yang mampu mengendalikan dan memanfaatkan perubahan sebagai pengaruh dari globalisasi. Pendidikan diharapkan mampu melestarikan kehidupan manusia, memberikan kehidupan manusiawi yang layak, mendukung hak asasi manusia di berbagai belahan dunia, dan mengantisipasi dampak-dampak kemajuan ilmu pengetahuan dan teknologi.

"Guru adalah pendidik profesional dengan tugas utama mendidik, mengajar, membimbing, mengarahkan, melatih, menilai, dan mengevaluasi peserta didik pada pendidikan anak usia dini jalur pendidikan formal, pendidikan dasar, dan pendidikan menengah" (Undang-Undang Republik Indonesia No. 14 Tahun 2005 tentang Guru dan Dosen, Bab I Pasal 1 Ayat 1). 
Berdasarkan hasil belajar siswa di kelas VI SDN 018 Kuok ternyata tingkat ketuntasan hasil ulangan siswa masih rendah yaitu 52,94 \% (9 orang) yang tuntas $(\mathrm{KKM}=70)$ dari 17 siswa. Hal tersebut terjadi kemungkinan ada bebarapa faktor yang menyebabkan banyak anak yang tidak tuntas diantaranya pengajaran Pendidkan Kewarganegaraan hanya menggunakan metode ceramah sehingga potensi yang ada pada peserta didik tidak maksimal selain itu siswa tidak mau bertanya pada saat pembelajaran kurang dimengertii. Berdasarkan permasalahan di atas penulis mencoba untuk melakukan penelitian dengan judul "Upaya meningkatkan hasil belajar mata pelajaran PKN melalui model pembelajaran kooperatif tipe STAD pada siswa kelas VI SDN 018 Kuok tahun pelajaran 2015/2016".

Tujuan penelitian tindakan kelas ini adalah: 1) untuk mengetahui apakah model pembelajaran kooperatif tipe STAD dapat meningkatkan perilaku aktivitas belajar siswa secara klasikal; 2) Untuk mengetahui apakah model pembelajaran kooperatif tipe STAD dapat meningkatkan perilaku aktivitas belajar kelompok; 3)untuk mengetahui apakah model pembelajaran kooperatif tipe STAD dapat meningkatkan hasil belajar siswa kelas VI SDN 018 Kuok tahun pelajaran 2015/ 2016.

Model pembelajaran kooperatif tipe Student Teams Achievment Division (STAD) dikembangkan oleh Robert E. Slavin dan teman-temannya di Universitas Jhon Hopkin, dan merupakan tipe pembelajaran kooperatif yang paling sederhana. Guru yang menggunakan STAD mengacu kepada belajar kelompok siswa yang menyajikaninformasi akademik kepada siswa menggunakan persentase verbal atau teks. Pembelajaran kooperatif tipe STAD membagi siswa dalam kelompok-kelompok kecil yang terdiri dari 4-5 orangyang bersifat heterogen. Komponen utama tipe STAD adalah persentase kelas, kegiatan kelompok, kuis/tes, pemberian skor indiVidu dan penghargaan kelompok.

Model pembelajaran kooperatif tipe Student Teams AchieVment DiVision (STAD) cocok untuk diterapkan bagi sekolah-sekolah yang masih menggunakan modelpembelajaran secara langsung karena sangat mudah diterapkan dan paling sederhana dalam penerapannya. Siswa akan lebih mudah menemukan dan menangani konsep-konsep yang sulit jika mereka saling mendiskusikan masalah tersebut dengan temannya. Siswa yang berkemampuan rendah mendapat kesempatan untuk dibimbing temannya yang memiliki wawasan lebih tinggi, sedangkan siswa yang lebih tinggi kemampuannya mempunyai kesempatan untuk menjadi tutor sehingga pemahamannya menjadi lebih baik lagi. Kerja kelompok diharapkan dapat membuat siswa lebih mendiskusikan konsep dan prinsip tentang pelajaran mereka. Kegiatan saling membantu 
yang menguntungkan semua pihak tentu akan meningkatkan hasil belajar siswa sehingga aktivitasnyapun meningkat pula.

Model pembelajaran kooperatif yang dipilih adalah Student Teams Achievement Division (STAD). STAD merupakan pendekatan pembelajaran kooperatif yang paling sederhana. Siswa dikelompokkan menjadi kelompok kecil 4-5 orang.Setiap kelompok dibuat heterogen terdiri dari laki-laki dan perempuan, siswa yang memiliki kemampuan tinggi, sedang, dan rendah. Setiap anggota saling membantu untuk memahami materi pelajaran. Secara indiVidu siswa juga diberi kuis yang hasilnya diberi skor peningkatan indiVidu dan kelompok.

Dalam pembelajaran kooperatif tipe STAD ada lima tahapan dalam pembelajaran sebagai berikut.

1. Presentasi kelompok (classpresentation)

2. Materi pembelajaran mula-mula disampaikan dalam presentasi kelas. Metode yang digunakan pembelajaran langsung atau diskusi kelas yang dipandu guru.

3. Kerja kelompok (Teams works)

4. Setiap kelompok terdiri atas 4-5 siswa yang heterogen laki-laki dan perempuan, berasal dari berbagai suku,memiliki kemampuan berbeda. Fungsi utama dari kelompok adalah menyiapkan anggota kelompok agar mereka dapat mengerjakan kuis dengan baik.

5. Kuis (quizzes)

6. Setelah 1-2 periode presentasi, dari 1-2 periode kerja kelompok, siswa diberi kuis individu. Siswa tidak diperbolehkan membantu satu sama yang lain selama kuis berlangsung. Siswa bertanggungjawab mempelajari materi yang telah disampaikan.

7. Penghargaan kelompok (teams recognation)

Kelompok mendapat penghargaan jika rata-rata skor kelompok melebihi kreteria tertentu. Sebelum menilai proses pembelajaran kelompok, guru menjelaskan beberapa aturan kelompok yang harus diharapkan.

Langkah-langkah pembelajaran model kooperatif tipe STAD adalah sebagai berikut.

1. Membentuk kelompok yang anggotanya 5 orang secara heterogen (campuran menurut prestasi, jenis kelamin, suku dll).

2. Guru menyajikan pelajaran.

3. Guru memberi tugas kepada kelompok untuk dikerjakan oleh angota-anggota kelompok. Anggotanya yang sudah mengerti dapat menjelaskan pada anggota lainnya sampai semua anggota dalam kelompok mengerti. 
4. Guru memberi kuis/pertanyaan kepada seluruh siswa. Pada saat menjawab kuis tidak boleh saling membantu.

5. Memberi evaluasi.

6. Kesimpulan.

Belajar merupakan suatu proses kegiatan yang dilakukan agar terjadi suatu perubahan tingkah laku pada seseorang, dari tidak tahu menjadi tahu, dan dari tidak mengerti menjadi mengerti, sebagai akibat dari interaksi seseorang dengan lingkungannya. Perubahan yang terjadi pada diri seseorang tersebut merupakan hasil yang diperoleh melalui proses belajar.

Menurut Dimyati dan Mudjiono (2009: 250) Hasil belajar merupakan tingkat perkembangan mental yang lebih baik yang dimiliki oleh seorang siswa yang terwujud dalam ranah kognitif, afektif, dan psikomotor dibandingkan dengan sebelum siswa belajar, yang dilihat dari sisi siwa. Sedangkan dari sisi guru, hasil belajar merupakan dimana saat terselesainya bahan pelajaran yang di sampaikan.

Oemar Hamalik (2004: 30) menjelaskan bahwa,"Hasil belajar merupakan bukti terjadinya perubahan tingkah laku seseorang, yang tampak pada aspek-aspek seperti; aspek pengetahuan, pengertian, kebiasaan, keterampilan, apresiasi, emosional, hubungan sosial, jasmani, etis budi pekerti, dan sikap."

Sukardi (20095) menerangkan bahwa hasil belajar adalah "nilai yang menunjukkan pencapaian hasil belajar siswa."

Berdasarkan penjelasan diatas, dapat ditarik kesimpulan bahwa hasil belajar merupakan bentuk kemampuan dan kecerdasan yang diperoleh siswa sebagai hasil dari proses belajar yang meliputi aspek kognitif, afektif, dan psikomotor.

Hasil belajar yang dicapai seseorang merupakan hasil dari interaksi berbagai faktor yang mempengaruhinya baik dari dalam maupun dari luar diri individu.

Faktor-faktor yang mempengaruhi hasil belajar yaitu sebagai berikut:

1) Faktor internal terdiri dari

a) Faktor jasmaniyah baik yang bersifat bawaan maupun yang diperoleh.Misalnya; penglihatan, pendengaran, struktur tubuh.

b) Faktor psikologis baik yang bersifat bawaan maupun yang diperoleh terdiri atas:

(1) Faktor intelektual yang meliputi:

Faktor potensial yaitu kecerdasan dan bakat.

(2) Faktor kecakapan nyata yaitu prestasi yang telah dimiliki. 
(3) Faktor non-intelektif, yaitu unsure-unsur kepribadian tertentu seperti sikap, kebiasaan, minat, kebutuhan, motiVasi, emosi, dan penyesuaian diri.

2) Faktor Eksternal terdiri dari: Faktor sosial, Faktor budaya, Faktor lingkungan fisik, Faktor lingkungan spiritual atau keamanan.

\section{METODE}

Penelitian ini dilakukan melalui empat tahap, yakni perencanaan, tindakan, observasi (penilaian), dan refleksi yang akan dilakukan sebanyak dua siklus masing masing siklus terdiri dari tiga kali pertemuan. Subjek penelitian ini adalah siswa kelas VI SDN 018 Kuok Kecamatan Kuok Kabupaten Kampar Tahun Pelajaran 2015/ 2016. Jumlah peserta didik sebagai subjek penelitian adalah 17 orang yang terdiri dari 8 putra dan 9 putri.

Pengamatan Perilaku Aktivitas Belajar Siswa secara Klasikal. Sumber data yang berupa perilaku aktivitas belajar siswa meliputi aspek: kedisiplinan, kesiapan belajar, keberanian, panggung jawab, dan pemahaman Tugas. Pengamatan Perilaku Aktivitas Belajar Kelompok. Sumber data yang berupa perilaku aktivitas kerja kelompok, kriterianya adalah: kerjasama, menyelesaikan masalah, percaya diri, dan hasil kerja kelompok. Pengamatan hasil helajar adalah hasil tes pembelajaran siswa yang diberikan guru atau peneliti pada setiap akhir pertemuan.

Pengumpulan data dilakukan dengan beberapa cara yakni pengamatan Perilaku Aktivitas Belajar Siswa secara Klasikal. Melakukan pengamatan terhadap perilaku aktivitas belajar siswa secara klasikal selama proses pembelajaran berlangsung dalam hal ini peneliti dibantu oleh seorang guru teman sejawat yang sudah cukup berpengalaman, yaitu Bapak Ali Nuhar, S.Pd.SD untuk melakukan pengamatan perilaku aktivitas belajar siswa dan mencatat hal-hal yang dilakukan siswa.

Melakukan Observasi terhadap kegiatan kerja kelompok. Untuk mengamati kegiatan kerja kelompok digunakan instrumen pengamatan perilaku aktivitas kerja kelompok. Masing-masing kelompok diamati dan dicatat pada instrumen yang sama.

Untuk memperoleh hasil belajar siswa setiap individu dan tingkat ketercapaian tujuan pembelajaran. Peneliti melakukan Tes Pembelajaran terhadap siswa, dengan menggunakan instrumen tes tertulis yang berjumlah 5 butir soal. Hasil tes yang merupakan hasil belajar siswa dicatat pada daftar nilai ulangan harian siswa.

Ketuntasan belajar ditinjau dari aspek perilaku aktivitas siswa peneliti melakukan penjumlahan skor yang diperoleh seluruh siswa, yang selanjutnya dibagi 
dengan jumlah siswa yang ada di kelas tersebut dikalikan skor maksimal hasilnya dikalikan 100, sehingga dapat dirumuskan:

$$
\mathrm{P}=\quad \begin{gathered}
\text { Jumlah semua skor siswa yang hadir } \\
\text { Jumlah siswa } \mathrm{x} \text { skor maksimal }
\end{gathered}
$$

Sedangkan untuk perilaku aktivitas kerja kelompok digunakan rumus :

Jumlah semua skor kelompok

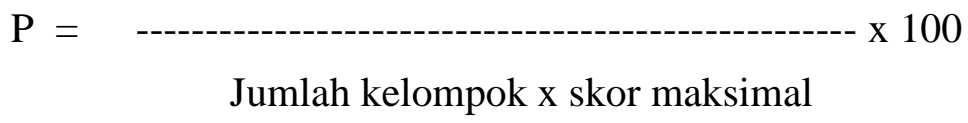

Dengan penskoran sebagai berikut :

$$
\begin{array}{llll}
90-100 & =\text { Amat Baik } & 60-69 & =\text { Sedang } \\
80-89 & =\text { Baik } & \leq 59 & =\text { Kurang } \\
70-79 & =\text { Cukup } & &
\end{array}
$$

Untuk mengetahui tingkat ketuntasan hasil belajar siswa, siswa dapat dinyatakan tuntas belajar apabila siswa tersebut telah mecapai nilai sesuai kriteria ketuntasan minimal mata pelajaran PKn kelas VI SDN 018 Kuok yang ditetapkan oleh sekolah. Kriteria ketuntasan minimal untuk mata pelajaran PKn kelas VI adalah 70\% atau nilai 70. Jadi siswa dapat dinyatakan tuntas belajar apabila telah mencapai skor $70 \%$ atau nilai 70 .

Untuk menghitung ketuntasan belajar secara klasikal peneliti menggunakan rumus sebagai berikut yaitu :

Jumlah siswa tuntas belajar

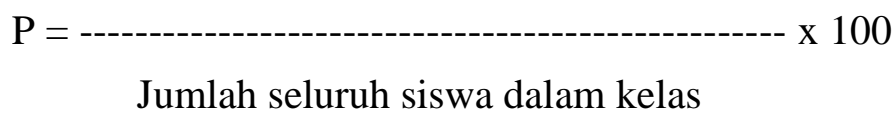

\section{HASIL DAN PEMBAHASAN}

Berdasarkan hasil observasi dan penilaian maka hal-hal yang perlu mendapat peningkatan pada pertemuan berikutnya adalah: perilaku aktivitas belajar siswa secara klasikal nilai aspek kedisiplinan 66,67 dengan katagori sedang, kesiapan belajar 68,63 dengan katagori sedang, keberanian 68,63 dengan katagori sedang, tanggung jawab 52,94 dengan katagori kurang dan pemahaman tugas 58,82, maka semua aspek harus ditingkatkan agar lebih baik lagi.

Perilaku aktivitas belajar kelompok nilai aspek kerjasama 58,33 dengan katagori kurang, menyelesaikan masalah 58,33 dengan katagori kurang, percaya diri 50 dengan katagori kurang, dan hasil kerja kelompok 83,33 dengan katagori cukup, maka semua aspek harus ditingkatkan agar lebih baik lagi. 
Data hasil belajar siswa menunjukkan rata-rata kelas 65,29 dengan katagori sedang namun persentase yang tuntas $52,94 \%$ atau masih ada 8 siswa yang belum tuntas yaitu nomor absen $2,3,7,12,14,15,16$ dan 17 sehingga 8 siswa ini diberikan remedial.

Berdasarkan hasil pembahasan peneliti dan pengamat terhadap pembelajaran pada penerapan model pembelajaran kooperatif tipe STAD siswa yang lebih aktif karena belajar secara kelompok sehingga dalam pembelajaran bukan guru yang aktif (teaching oriented) tetapi siswa yang aktif dan belajar sangat menyenangkan namun masih ada kekurangan pengaturan waktu yang dilakukan guru pada saat kegiatan siswa dalam kelompok selain itu diharapkan guru terus mengumumkan hasil rekapitulasi perilaku aktivitas belajar siswa dan perilaku Aktivitas Belajar Kelompok setiap akhir pertemuan agar siswa memperbaiki pada pertemuan berikutnya.

\section{Siklus 1 Pertemuan 2}

1). Perilaku Aktifitas Belajar Siswa secara Klasikal

Hasil pengamatan perilaku aktifitas belajar siswa secara klasikal pada pertemuan ke-2 dengan penerapan model pembelajaran kooperatif tipe STAD diperoleh data sebagai berikut :

\begin{tabular}{llccc}
\hline No & Aktivitas Belajar Siswa & $\begin{array}{c}\sum \text { siswa x } \\
\text { skor max 3 }\end{array}$ & $\begin{array}{c}\text { Jumlah } \\
\text { Skor }\end{array}$ & Nilai Skor \\
\hline 1 & Kedisiplinan & 17 & 38 & 74,51 \\
2 & Kesiapan Belajar & 17 & 37 & 72,55 \\
3 & Keberanian & 17 & 38 & 74,51 \\
4 & Tanggung jawab & 17 & 30 & 58,82 \\
5 & Pemahaman Tugas & 17 & 30 & 58,82 \\
\hline
\end{tabular}

2). Perilaku Aktivitas Belajar Kelompok

Adapun hasil pengamatan perilaku aktivitas belajar kelompok pada pertemuan ke-2 dengan penerapan model pembelajaran kooperatif tipe STAD diperoleh data sebagai berikut : 


\begin{tabular}{ccccc}
\hline No & $\begin{array}{c}\text { Perilaku Aktivitas Belajar } \\
\text { Kelompok }\end{array}$ & $\begin{array}{c}\sum \text { kelompok } \\
\text { x skor max 3 }\end{array}$ & $\begin{array}{c}\text { Jumlah } \\
\text { Skor }\end{array}$ & Nilai Skor \\
\hline 1 & Kerjasama & 4 & 9 & 75 \\
2 & Menyelesaikan masalah & 4 & 7 & 58,33 \\
3 & Percaya diri & 4 & 8 & 66,67 \\
4 & Hasil Kerja Kelompok & 4 & 10 & 83,33 \\
\hline
\end{tabular}

3). Hasil Belajar Siswa

Hasil belajar siswa pada pertemuan ke- 2 dengan penerapan model pembelajaran kooperatif tipe STAD diperoleh data sebagai berikut:

Tabel 4.9 Hasil Belajar Siswa S.1 P.2

\begin{tabular}{cccc}
\hline No & Ketuntasan & Jumlah & Persentase \\
\hline 1 & Tuntas & 11 & $64,71 \%$ \\
2 & Tidak Tuntas & 6 & $35,29 \%$ \\
\hline
\end{tabular}

Berdasarkan hasil observasi dan penilaian maka hal-hal yang perlu mendapat peningkatan pada pertemuan berikutnya adalah: perilaku aktivitas belajar siswa secara klasikal nilai aspek kedisiplinan 74,51 dengan katagori cukup, kesiapan belajar 72,55 dengan katagori cukup, keberanian 74,51 dengan katagori cukup, tanggung jawab 58,82 dengan katagori kurang dan pemahaman tugas 58,82 dengan katogori kurang sehingga aspek kedisiplinan, kesiapan belajar dan keberanian sudah cukup tetapi aspek yang harus diperhatikan lagi nilainya; perilaku aktivitas belajar kelompok nilai aspek kerjasama 75 dengan katagori cukup, menyelesaikan masalah 58,33 dengan katagori kurang, percaya diri 66,67 dengan katagori sedang, dan hasil belajar kelompok 83,33 dengan katagori baik sehingga aspek hasil belajar kelompok siswa sudah baik namun aspek yang lain harus ditingkatkan lagi; dan data hasil belajar siswa menunjukkan ratarata kelas 72,94 dengan katagori cukup dan meningkat dari pertemuan sebelumnya tetapi persentase yang tuntas hanya 64,71\% atau masih ada 6 siswa yang belum tuntas yaitu nomor absen 2, 7, 14, 15, 16 dan 17.

Pada siklus 1 pertemuan ke 2 kelebihan penerapan model pembelajaran kooperatif tipe STAD siswa terlihat lebih aktif sehingga pembelajaran lebih menarik dan suasana belajar menyenangkan dan siswa berlomba - lomba mencari nilai terbaik karena nilai perilaku aktivitas kerja kelompok diumumkan guru nilai siapa yang terbaik selain itu juga terdapat kekurangan yaitu kurangnya pengaturan waktu yang dilakukan guru pada saat siswa berkerja secara kelompok dan cara menyelesaikan masalah dalam 
kelompok untuk menjawab LKS kurang untuk berkerja sama mencari jawaban LKS hanya siswa yang pintar yang banyak bekerja selain itu siswa kurang percaya diri di depan kelas untuk persentas hasil kerja kelompoknya, untuk pertemuan selanjutnya guru lebih memperhatikan dan menegur siswa yang tidak bekerja dalam kelompok.

\section{Siklus 1 Pertemuan 3}

1). Perilaku Aktifitas Belajar Siswa secara Klasikal

Hasil pengamatan perilaku aktifitas belajar siswa pada pertemuan ke-3 dengan penerapan model pembelajaran kooperatif tipe STAD diperoleh data:

\begin{tabular}{ccccc}
\hline No & $\begin{array}{c}\text { Perilaku Aktivitas Belajar } \\
\text { Siswa }\end{array}$ & $\begin{array}{c}\sum \text { siswa x } \\
\text { skor max 3 }\end{array}$ & $\begin{array}{c}\text { Jumlah } \\
\text { Skor }\end{array}$ & Nilai Skor \\
\hline 1 & Kedisiplinan & 16 & 38 & 79,17 \\
2 & Kesiapan Belajar & 16 & 37 & 77,08 \\
3 & Keberanian & 16 & 38 & 79,17 \\
4 & Tanggung jawab & 16 & 31 & 64,58 \\
5 & Pemahaman Tugas & 16 & 31 & 64,58 \\
\hline
\end{tabular}

2). Perilaku Aktivitas Belajar Kelompok

Adapun hasil pengamatan perilaku aktivitas belajar kelompok pada pertemuan ke-3 dengan penerapan model pembelajaran kooperatif tipe STAD data sebagai berikut

\begin{tabular}{ccccc}
\hline No & $\begin{array}{c}\text { Perilaku Aktivitas } \\
\text { Belajar Kelompok }\end{array}$ & $\begin{array}{c}\text { ¿ kelompok } \\
\text { x skor max 3 }\end{array}$ & $\begin{array}{c}\text { Jumlah } \\
\text { Skor }\end{array}$ & Nilai Skor \\
\hline 1 & Kerjasama & 4 & 9 & 75 \\
2 & Menyelesaikan masalah & 4 & 10 & 83,33 \\
3 & Percaya diri & 4 & 9 & 75 \\
4 & Hasil Kerja Kelompok & 4 & 11 & 91,67 \\
\hline
\end{tabular}

3). Hasil Belajar Siswa

Hasil belajar siswa pada pertemuan ke-3 dengan penerapan model pembelajaran kooperatif tipe STAD diperoleh data sebagai berikut :

\begin{tabular}{llll}
\hline No & Ketuntasan & Jumlah & Persentase \\
\hline
\end{tabular}




\begin{tabular}{llll}
\hline 1 & Tuntas & 11 & $68,75 \%$ \\
2 & Tidak Tuntas & 5 & $41,25 \%$ \\
\hline
\end{tabular}

Berdasarkan hasil observasi dan penilaian hasil belajar maka hal-hal yang perlu mendapat peningkatan pada pertemuan berikutnya adalah: Perilaku aktivitas belajar siswa secara klasikal nilai aspek kedisiplinan 79,17 dengan katagori cukup, kesiapan belajar 77,08 dengan katagori cukup, keberanian 79,17 dengan katagori cukup, tanggung jawab 64,58 dengan katagori sedang dan pemahaman tugas 64,58 dengan katogori sedang sehingga aspek tanggung jawab siswa dan pemahaman siswa dalam tugas yang dikerjakan harus ditingkatkan lagi agar mencapai nilai baik; perilaku aktivitas belajar kelompok nilai aspek kerjasama 75 dengan katagori cukup, menyelesaikan masalah 83,33 dengan katagori baik, percaya diri 75 dengan katagori cukup, dan hasil kerja kelompok 91,67 dengan katagori sangat baik sehinga aspek hasil kerja sudah sangat baik tetapi kerjasama siswa dalam kelompok nilainya menurun maka harus diperhatikan agar siswa nilainya lebih baik lagi; dan data hasil belajar siswa menunjukkan rata-rata kelas 78,75 dengan katagori masih cukup namun persentase yang tuntas $68,75 \%$ atau masih ada 5 siswa yang belum tuntas yaitu nomor absen 2,7 , 15,16 dan 17.

Pada siklus 2 pertemuan 3 menunjukkan adanya peningkatan setiap pertemuan namun guru harus menerapkan sikap tanggung jawab untuk mengerjakan soal penilaian hasil belajar selain itu guru menanamkan bagaimana cara kerjasama yang baik dalam kelompok agar siswa yang pintar membimbing temannya yang lain.

\section{Siklus 1 Pertemuan 4}

1). Perilaku Aktifitas Belajar Siswa secara Klasikal

Hasil pengamatan aktifitas belajar siswa pada pertemuan ke- 4 dengan penerapan model pembelajaran kooperatif tipe STAD diperoleh data berikut:

\begin{tabular}{llccc}
\hline No & $\begin{array}{c}\text { Perilaku Aktivitas Belajar } \\
\text { Siswa }\end{array}$ & $\begin{array}{c}\sum \text { siswa x } \\
\text { skor max 3 }\end{array}$ & $\begin{array}{c}\text { Jumlah } \\
\text { Skor }\end{array}$ & Nilai Skor \\
\hline 1 & Kedisiplinan & 17 & 41 & 80,39 \\
2 & Kesiapan Belajar & 17 & 41 & 80,39 \\
3 & Keberanian & 17 & 42 & 82,35 \\
4 & Tanggung jawab & 17 & 39 & 76,47 \\
5 & Pemahaman Tugas & 17 & 40 & 78,43 \\
\hline
\end{tabular}


2). Perilaku Aktivitas Belajar Kelompok

Adapun hasil pengamatan perilaku aktivitas belajar kelompok pada pertemuan ke- 4 dengan penerapan model pembelajaran kooperatif tipe STAD diperoleh data sebagai berikut :

\begin{tabular}{clccc}
\hline No & $\begin{array}{c}\text { Perilaku Aktivitas Belajar } \\
\text { Kelompok }\end{array}$ & $\begin{array}{c}\text { N kelompok x } \\
\text { skor max 3 }\end{array}$ & $\begin{array}{c}\text { Jumlah } \\
\text { Skor }\end{array}$ & Nilai Skor \\
\hline 1 & Kerjasama & 4 & 10 & 83,33 \\
2 & Menyelesaikan masalah & 4 & 10 & 83,33 \\
3 & Percaya diri & 4 & 9 & 75 \\
4 & Hasil Kerja Kelompok & 4 & 11 & 91,67 \\
\hline
\end{tabular}

3). Hasil Belajar Siswa

Hasil belajar siswa pada pertemuan ke- 4 dengan penerapan model pembelajaran kooperatif tipe STAD diperoleh data sebagai berikut:

\begin{tabular}{clcc}
\hline No & Ketuntasan & Jumlah & Persentase \\
\hline 1 & Tuntas & 13 & $76,47 \%$ \\
2 & Tidak Tuntas & 4 & $23,53 \%$ \\
\hline
\end{tabular}

Berdasarkan hasil observasi dan penilaian maka hal-hal yang perlu mendapat peningkatan pada pertemuan berikutnya adalah: Perilaku aktivitas belajar siswa secara klasikal nilai aspek kedisiplinan 80,39 dengan katagori baik, kesiapan belajar 80,39 dengan katagori baik, keberanian 82,35 dengan katagori baik, tanggung jawab 76,47 dengan katagori cukup dan pemahaman tugas 78,43 dengan katogori cukup maka aspek tanggung jawab dan pemahaman tugas harus ditingkatkan lagi karena nilai nya masih cukup; Perilaku aktivitas belajar kelompok nilai aspek kerjasama 83,33 dengan katagori baik, menyelesaikan masalah 83,33 dengan katagori baik, percaya diri 75 dengan katagori cukup, dan hasil kerja kelompok 91,67 dengan katagori sangat baik sehingga hanya aspek percaya diri siswa yang harus ditingkatkan; dan data hasil belajar siswa menunjukkan rata-rata kelas 81,18 dengan katagori baik namun persentase yang tuntas $76,47 \%$ atau masih ada 4 siswa yang belum tuntas yaitu nomor absen 4, 15, 16 dan 17.

Pada siklus 2 pertemuan 4 pada pembelajaran PKn dengan penerapan model pembelajaran kooperatif tipe STAD menunjukkan adanya peningkatan pada siklus 1 namun guru masih harus menerapkan sikap tanggung jawab untuk mengerjakan soal 
penilaian hasil belajar selain itu guru member motivasi siswa untuk tampil percaya diri di depan kelas untuk mempersentasekan hasil kelompoknya agar siswa lebih berani lagi tampil di depan umum.

\section{Siklus 1 Pertemuan 5}

1). Aktifitas Belajar Siswa secara Klasikal

Hasil pengamatan aktifitas belajar siswa pada pertemuan ke 5 dengan penerapan model pembelajaran kooperatif tipe STAD diperoleh data berikut:

\begin{tabular}{llccc}
\hline No & $\begin{array}{c}\text { Perilaku Aktivitas Belajar } \\
\text { Siswa }\end{array}$ & $\begin{array}{c}\sum \text { siswa x } \\
\text { skor } \max \text { 3 }\end{array}$ & $\begin{array}{c}\text { Jumlah } \\
\text { Skor }\end{array}$ & Nilai Skor \\
\hline 1 & Kedisiplinan & 15 & 39 & 86,67 \\
2 & Kesiapan Belajar & 15 & 39 & 96,67 \\
3 & Keberanian & 15 & 39 & 86,67 \\
4 & Tanggung jawab & 15 & 38 & 84,44 \\
5 & Pemahaman Tugas & 15 & 40 & 88,89 \\
\hline
\end{tabular}

2). Perilaku Aktivitas Belajar Kelompok

Adapun hasil pengamatan perilaku aktivitas belajar kelompok pada pertemuan ke- 5 dengan penerapan model pembelajaran kooperatif tipe STAD diperoleh data sebagai berikut :

\begin{tabular}{clccc}
\hline No & $\begin{array}{c}\text { Perilaku Aktivitas Belajar } \\
\text { Kelompok }\end{array}$ & $\begin{array}{c}\sum \text { kelompok x } \\
\text { skor } \max \mathbf{3}\end{array}$ & $\begin{array}{c}\text { Jumlah } \\
\text { Skor }\end{array}$ & Nilai Skor \\
\hline 1 & Kerjasama & 4 & 11 & 91,67 \\
2 & Menyelesaikan masalah & 4 & 10 & 83,33 \\
3 & Percaya diri & 4 & 10 & 83,33 \\
4 & Hasil Kerja Kelompok & 4 & 12 & 100 \\
\hline
\end{tabular}

3). Hasil Belajar Siswa

Hasil belajar siswa pada pertemuan ke- 5 dengan penerapan model pembelajaran kooperatif tipe STAD diperoleh data sebagai berikut:

\begin{tabular}{clcc}
\hline No & Ketuntasan & Jumlah & Persentase \\
\hline 1 & Tuntas & 13 & $86,67 \%$ \\
2 & Tidak Tuntas & 2 & $13,33 \%$ \\
\hline
\end{tabular}


Berdasarkan hasil observasi dan penilaian maka hal-hal yang perlu mendapat peningkatan pada pertemuan berikutnya adalah: Perilaku aktivitas belajar siswa secara klasikal nilai aspek kedisiplinan 86,67 dengan katagori baik, kesiapan belajar 86,67 dengan katagori baik, keberanian 86,67 dengan katagori baik, tanggung jawab 84,44 dengan katagori cukup dan pemahaman tugas 88,89 dengan katogori baik namun aspek tanggung jawab harus ditingkatkan lagi agar siswa tidak ada satu pun lagi yang mengharapkan hasil siswa lain; perilaku aktivitas belajar kelompok nilai aspek kerjasama 91,67 dengan katagori sangat baik, menyelesaikan masalah 83,33 dengan katagori baik, percaya diri 83,33 dengan katagori baik, dan hasil kerja kelompok 100 dengan katagori sangat baik; dan data hasil belajar siswa menunjukkan rata-rata kelas 84,00 dengan katagori baik namun persentase yang tuntas masih 86,67\% atau masih ada 2 siswa yang belum tuntas dari 15 siswa yang hadir yaitu nomor absen 15 dan 17 .

\section{Siklus 1 Pertemuan 5}

1). Aktifitas Belajar Siswa secara Klasikal

Hasil pengamatan aktifitas belajar siswa pada pertemuan ke- 6 dengan penerapan model pembelajaran kooperatif tipe STAD diperoleh data berikut:

\begin{tabular}{llccc}
\hline No & $\begin{array}{c}\text { Perilaku Aktivitas Belajar } \\
\text { Siswa }\end{array}$ & $\begin{array}{c}\sum \text { siswa x } \\
\text { skor max 3 }\end{array}$ & $\begin{array}{c}\text { Jumlah } \\
\text { Skor }\end{array}$ & Nilai Skor \\
\hline 1 & Kedisiplinan & 17 & 46 & 90,20 \\
2 & Kesiapan Belajar & 17 & 44 & 86,27 \\
3 & Keberanian & 17 & 46 & 90,20 \\
4 & Tanggung jawab & 17 & 45 & 88,24 \\
5 & Pemahaman Tugas & 17 & 45 & 88,24 \\
\hline
\end{tabular}

2). Perilaku Aktivitas Belajar Kelompok

Adapun hasil pengamatan perilaku ativitas belajar kelompok pada pertemuan ke- 6 dengan penerapan model pembelajaran kooperatif tipe STAD diperoleh data sebagai berikut :

\begin{tabular}{llccc}
\hline No & $\begin{array}{c}\text { Perilaku Aktivitas Belajar } \\
\text { Kelompok }\end{array}$ & $\begin{array}{c}\sum \text { kelompok x } \\
\text { skor max } 3\end{array}$ & $\begin{array}{c}\text { Jumlah } \\
\text { Skor }\end{array}$ & Nilai Skor \\
\hline 1 & Kerjasama & 4 & 10 & 83,33 \\
2 & Menyelesaikan masalah & 4 & 11 & 91,67 \\
3 & Percaya diri & 4 & 11 & 91,67 \\
\hline
\end{tabular}




\section{3). Hasil Belajar Siswa}

Hasil belajar siswa pada pertemuan ke- 6 dengan penerapan model pembelajaran kooperatif tipe STAD diperoleh data sebagai berikut:

\begin{tabular}{clcc}
\hline No & Ketuntasan & Jumlah & Persentase \\
\hline 1 & Tuntas & 16 & $94,12 \%$ \\
2 & Tidak Tuntas & 1 & $5,88 \%$ \\
\hline
\end{tabular}

Berdasarkan hasil observasi dan penilaian maka hal-hal yang perlu mendapat peningkatan pada pertemuan berikutnya adalah: Perilaku aktivitas belajar siswa secara klasikal nilai aspek kedisiplinan 90,20 dengan katagori sangat baik, kesiapan belajar 86,27 dengan katagori baik, keberanian 90,20 dengan katagori sangat baik, tanggung jawab 88,24 dengan katagori baik dan pemahaman tugas 88,24, maka semua aspek sudah mencapai nilai baik dan memuaskan peneliti; Perilaku aktivitas belajar kelompok nilai aspek kerjasama 83,33 dengan katagori baik, menyelesaikan masalah 91,67 dengan katagori sangat baik, percaya diri 91,67 dengan katagori sangat baik, dan hasil kerja kelompok 100, maka semua aspek nilainya sudah sesuai dengan keinginan peneliti; Data hasil belajar siswa menunjukkan rata-rata kelas 88,24 dengan katagori baik dan persentase yang tuntas $94,12 \%$ atau masig ada 1 siswa yang belum mencapai KKM yaitu nomor absen 16.

Berdasarkan hasil refleksi siklus 2, peneliti tidak melakukan rencana perbaikan untuk siklus selanjutnya karena hasil yang diinginkan telah sesuai dengan rencana pembelajaran nilai perilaku aktivitas belajar siswa secara klasikal, perilaku aktivitas belajar kelompok dan hasil belajar siswa setiap [ertemuan mengalami peningkatan dan pada saat tes pembelajaran 94,12 \% siswa mencapai KKM atau masih ada 1 siswa yang belum tuntas.

\section{Pembahasan Hasil Penelitian}

Melalui pengumpulan data selama 2 siklus dengan 6 kali pertemuan setiap siklusnya maka dapat dibandingkan siklus 1 dan siklus 2 seperti berikut ini : 


\begin{tabular}{clll}
\hline Sumber Data & \multicolumn{1}{c}{ Aspek } & \multicolumn{1}{c}{ Siklus 1 } & \multicolumn{1}{c}{ Siklus 2 } \\
\hline Nilai Perilaku & Kedisiplinan & 73,45 (Cukup) & 85,75 (Baik) \\
Aktivitas Belajar & Kesiapan Belajar & 72,75 (Cukup) & 84,44 (Baik) \\
secara Klasikal & Keberanian & 74,10 (Cukup) & 86,41 (Baik) \\
& Tanggung jawab & 58,78 (Kurang) & 83,05 (Baik) \\
& Pemahaman Tugas & 60,74 (Sedang) & 85,19 (Baik) \\
Nilai Perilaku & & & \\
Aktivitas Kerja & Kerjasama & 69,44 (Sedang) & 86,11 (Baik) \\
Kelompok & Menyelesaikan masalah & 66,66 (Sedang) & 86,11 (Baik) \\
& Percaya diri & 63,89 (Kurang) & 83,33 (Baik) \\
& Hasil Kerja Kelompok & 86,11 (Baik) & 97,22 (Baik) \\
Nilai Hasil & & & $1 \leq$ KKM \\
Belajar & KKM =70 & $8 \leq$ KKM & $94,12 \%$ \\
& Tuntas & $52,94 \%$ & 84,47 \\
\hline
\end{tabular}

Secara umum dari siklus 1 ke siklus 2 mengalami kenaikan atau peningkatan yang sangat signifikan perilaku aktivitas belajar siswa secara klasikal, perilaku aktivitas kerja kelompok dan hasil belajar siswa. Hal ini menunjukkan bahwa dengan penerapan model pembelajaran kooperatif tipe STAD pada pembelajaran PKn kelas VI SDN 018 Kuok dapat meningkatkan hasil belajar siswa, siswa lebih aktif dalam pembelajaran dan suasana belajar sangat menyenangkan sehingga prestasi belajar siswa juga meningkat.

\section{SIMPULAN DAN SARAN}

\section{Simpulan}

Penerapan model pembelajaran kooperatif tipe STAD dapat meningkatkan perilaku aktivitas belajar siswa secara klasikal kelas VI SDN 018 Kuok tahun pelajaran 2015/ 2016 semestre Genap setiap pertemuan. Menggunakan model pembelajaran kooperatif tipe STAD dapat meningkatkan perilaku aktivitas belajar kelompok kelas VI SDN 018 Kuok setiap pertemuannya. Meningkatnya perilaku aktivitas belajar siswa dan perilaku aktivitas kerja kelompok dengan penerapan meodel pembelajaran kooperatif tipe STAD maka hasil belajar siswa kelas VI SDN 018 Kuok setiap pertemuan meningkat. 


\section{Saran}

Penggunaan model pembelajaran kooperatif tipe STAD dapat dijadikan sebagai salah satu alternatif bagi guru sebagai strategi pembelajaran karena siswa lebih aktif dalam belajar. Jika akan menggunakan model pembelajaran kooperatif tipe STAD guru lebih memperhatikan dan membagi waktu dengan baik.

\section{DAFTAR PUSTAKA}

Anita L. (2010). Mempraktikkan Cooperative Learning di Ruang-ruang Kelas. Gramedia. Jakarta.

Arikunto, Suharsimi.( 2009). Penelitian Tindakan Kelas. Jakarta: Pustaka Baru.

Dimyati dan Mudjiono. (2006). Belajar dan Pembelajaran. Rineka Cipta. Jakarta.

Hadari, N. (2004). Metode-Metode Mengajar. Jakarta. Pustaka Pelajar.

Hamalik, O. (2005). Proses Belajar Mengajar. Jakarta. Bina Aksara.

Isjoni. (2008). Model-model Pembelajaran Mutakhir. Alfabeta. Bandung.

Rusman. (2010). Model-model Pembelajaran Mengembangkan Profesionalisme Guru. Mulya Mandiri Pers. Bandung.

Sanjaya, W. (2009). Strategi Pembelajaran Berorientasi Standar Proses Pendidikan. Kencana. Jakarta.

Suprijono, A. (2009). Cooperative Leraning Teori dan Aplikasi Paikem. Pustaka Pelajar. Yogyakarta

Syahrilfuddin, dkk. (2011). Bahan Ajar Penelitian Tindakan Kelas. UNRI. Pekanbaru. 